\title{
Femoral Heads from Total Hip Arthroplasty as a Source of Adult Hematopoietic Cells
}

\author{
Anthony D. Pomicter ${ }^{a}$ Phillip M. Clair ${ }^{a}$ Dongqing Yan ${ }^{a}$ \\ William L. Heaton ${ }^{a}$ Anna M. Eiring ${ }^{a}$ Michael B. Anderson ${ }^{b}$ \\ Stephen M. Richards ${ }^{b}$ Jeremy Gililland ${ }^{b}$ Thomas O'Hare ${ }^{a, c}$ \\ Michael W. Deininger ${ }^{a, c}$
}

${ }^{a}$ Huntsman Cancer Institute, University of Utah, Salt Lake City, UT, USA; bepartment of Orthopaedic Surgery, University of Utah, Salt Lake City, UT, USA; 'Division of Hematology and Hematologic Malignancies, University of Utah, Salt Lake City, UT, USA

\section{Keywords \\ CD34 · Age-matched control $\cdot$ Hematopoiesis}

\begin{abstract}
Normal human bone marrow cells are critical for studies of hematopoiesis and as controls to assess toxicity. As cells from commercial vendors are expensive, many laboratories resort to cancer-free bone marrow specimens obtained during staging or to umbilical cord blood cells, which may be abnormal or reflect a much younger age group compared to the disease samples under study. We piloted the use of femoral heads as an alternative and inexpensive source of normal bone marrow. Femoral heads were obtained from 21 successive patients undergoing elective hip arthroplasty. Mononuclear cells (MNCs) were purified with Ficoll, and $\mathrm{CD}^{+}, \mathrm{CD}_{14}{ }^{+}$, and $\mathrm{CD} 34^{+}$cells were purified with antibodycoated microbeads. The median yield of MNCs was $8.95 \times$ $10^{7}$ (range, $1.62 \times 10^{5}-2.52 \times 10^{8}$ ), and the median yield of CD34 ${ }^{+}$cells was $1.40 \times 10^{6}$ (range, $3.60 \times 10^{5}-9.90 \times 10^{6}$ ). Results of downstream applications including qRT-PCR, colony-forming assays, and ex vivo proliferation analysis were of
\end{abstract}

karger@karger.com www.karger.com/aha

(c) 2021 S. Karger AG, Base

Karger ${ }^{\prime}=$ high quality and comparable to those obtained with standard bone marrow aspirates. We conclude that femoral heads currently discarded as medical waste are a cost-efficient source of bone marrow cells for research use.

(c) 2021 S. Karger AG, Basel

\section{Introduction}

Normal bone marrow cells are frequently required as controls in experiments related to the pathogenesis and therapy of leukemia or in studies of hematopoiesis. As most myeloid neoplasms are diagnosed in patients aged 50-70 years or older, it is important to use age-matched controls to avoid experimental bias, given that aging causes profound changes in marrow composition and cellular functionality $[1,2]$. In practice, however, umbilical cord blood (CB) is frequently used as a source of healthy hematopoietic cells $[3,4]$, reflecting ease of access

Anthony D. Pomicter and Phillip M. Clair contributed equally to this study. 
and/or lower cost compared to bone marrow from volunteers or commercial vendors [5-7]. To identify alternative sources of hematopoietic cells as controls for studies of adult leukemia, we piloted the use of bone marrow cells extracted from the femoral heads of patients requiring elective total hip arthroplasty (THA). While we are not the first to use hematopoietic cells derived from femoral heads for laboratory studies [7-9], we are the first to report the abundances of cells derived from this unique source. We demonstrate that sufficient cells are recovered to perform functional studies, justifying the investment of time and resources required to establish the logistics. Our results suggest that femoral head marrow is a reliable and cost-efficient source of normal control cells for use in research.

\section{Materials and Methods}

\section{Recovery of Hematopoietic Cells from Femoral Heads}

Patients requiring THA were screened to eliminate those with a history of cancer and those on immunosuppressive therapy. Written informed consent was obtained (University of Utah, IRB 77125) from all patients. Femoral heads were collected immediately following surgical removal and transported from the orthopedic center to the laboratory under aseptic conditions. In a laminar flow hood, an electric drill (Makita model LXT with an 18-volt lithium ion battery, set to low speed) and an ethanol-sterilized 0.25 -inch stainless steel drill bit were used to penetrate the bone, and the opening was flushed with cold RPMI (Invitrogen/Thermo Fisher Scientific, Carlsbad, CA, USA). The process was repeated multiple times, consuming $200-400 \mathrm{~mL}$ of RPMI. The medium containing the cells was collected in a $150 \times 20 \mathrm{~mm}$ tissue culture dish, filtered through a $70-\mu \mathrm{m}$ nylon cell strainer (BD Biosciences, San Jose, CA, USA) into 50-mL tubes, and centrifuged at $185 \mathrm{~g}$. Cell pellets were subjected to 2 rounds of red blood cell lysis using standard ammonium-chloride-potassium buffer. The resulting whole white bone marrow cell fraction was resuspended in phosphate buffered saline (D-PBS; Invitrogen) and layered over Ficoll (GE Healthcare, Chicago, IL, USA) and centrifuged at $425 \mathrm{~g}$ for $20 \mathrm{~min}$ at room temperature with no brake. The mononuclear cell (MNC) fraction was removed and washed in D-PBS, and the yield was determined with Guava ViaCount Reagent (Millipore, Burlington, MA, USA) on a Guava easyCyte 6HT-2L benchtop flow cytometer (Millipore). When the MNC yield exceeded $2 \times 10^{7}, \mathrm{CD}^{+} 4^{+}$cells were purified with antibody-coated microbeads using an autoMACS Pro Separator (Miltenyi Biotec, Bergisch Gladbach, Germany). CD3 and CD14 cells were purified from either CD34- or total MNCs with the same approach (Table 1). Cells were frozen in $1 \mathrm{~mL}$ of a solution of 50\% RPMI-1640, 40\% fetal bovine serum, and $10 \%$ DMSO. Cells were stored in a Mr. Frosty Freezing Container (Thermo Scientific) with isopropyl alcohol at $-80^{\circ} \mathrm{C}$ for $1-5$ days, then moved to liquid nitrogen. Upon retrieval, vials were placed in a water bath set to $37^{\circ} \mathrm{C}$ for $2 \mathrm{~min}$, cell solution was transferred to $5 \mathrm{~mL}$ of RPMI-1640 and centrifuged at $500 \mathrm{~g}$ for $5 \mathrm{~min}$ at $4^{\circ} \mathrm{C}$, and the supernatant was discarded.

Femoral Heads as a Source of Adult Hematopoietic Cells
Table 1. Cellular fractions purified from femoral heads

\begin{tabular}{ll}
\hline Positive fractions & Negative fractions \\
\hline $\mathrm{CD} 34^{+}$ & $\mathrm{CD} 34^{-}$ \\
$\mathrm{CD}^{-} 4^{-} \mathrm{CD}^{+}$ & $\mathrm{CD} 34^{-} \mathrm{CD}^{-}$ \\
$\mathrm{CD} 34^{-} \mathrm{CD} 14^{+}$ & $\mathrm{CD} 34^{-} \mathrm{CD} 14^{-}$ \\
\hline
\end{tabular}

\section{Umbilical CB Cells}

Umbilical CB was obtained from The St. Louis Cord Blood Bank at SSM Cardinal Glennon Children's Medical Center. In 1 case, CB was collected under a separate IRB at a local hospital after informed consent (IRB 00392). MNCs were prepared as above, and CD $34^{+}$cells were separated with an autoMACS Pro Separator, as described above.

\section{Evaluation of Cell Purity}

Following selection on the autoMACS Pro, the cells were incubated with $0.5 \%$ bovine serum albumin, $\mathrm{F}_{\mathrm{c}}$ block (eBioscience/ Thermo Fisher Scientific, Waltham, MA, USA), anti-CD45-APC (clone HI30; Tonbo Biosciences, San Diego, CA, USA), and the appropriate antibody, then washed and analyzed on a Guava $6 \mathrm{HT}$ flow cytometer (Millipore). Antibodies were CD3-PE (clone HIT3a; BioLegend, San Diego, CA, USA), CD14-PE (clone 61D3; Tonbo Biosciences), and CD34-PE (clone 4H11; eBiosciences). Data were analyzed with FlowJo Software version 10 for Windows (Ashland, OR, USA).

\section{Hematopoietic Colony-Forming Unit Assay}

Femoral head or CB CD34+ cells were cultured for $72 \mathrm{~h}$ in RPMI supplemented with 10\% FBS (Sigma-Aldrich, St. Louis, MO, USA), $50 \mathrm{ng} / \mathrm{mL}$ SCF, and $10 \mathrm{ng} / \mathrm{mL}$ IL-3 (PeproTech, Cranbury, NJ, USA), then plated in duplicate $\left(2 \times 10^{3}\right.$ per dish) in MethoCult H4230 (StemCell Technologies, Vancouver, BC, Canada) with the same cytokines at the same concentrations. Colonies were enumerated after 9-14 days.

\section{Western Blot}

Femoral head and umbilical CB CD $34^{+}$cells were selected on an AutoMACS Pro and lysed in RIPA buffer containing protease and phosphatase inhibitors (Cell Signaling Technology, Danvers, MA, USA) with $1 \mathrm{mM}$ PMFS added immediately prior to use, and stored at $-80^{\circ} \mathrm{C}$. Lysate (equivalent to $1.3 \times 10^{5}$ cells/lane) was electrophoresed on a mini-Protean TGX Gel (Bio-Rad, Hercules, CA, USA), transferred to nitrocellulose ( $0.45 \mu \mathrm{m}$ pore size; Bio-Rad), blocked in 5\% non-fat milk for $30 \mathrm{~min}$, and incubated with monoclonal anti- $\beta$-actin (clone 8H10D10; Cell Signaling Technology) overnight at $4^{\circ} \mathrm{C}$. The next day, the blot was washed in PBSTween-20 (0.01\%) and incubated with donkey anti-rabbit IgG conjugated to IRDye $800 \mathrm{CW}$ (LI-COR Biosciences, Lincoln, NE, USA) for $2 \mathrm{~h}$ at room temperature, then washed in PBS-Tween-20. Images were captured with an Odyssey Imaging System (LI-COR Biosciences) at intensity 3.0. Quantification was performed with Image Studio Lite Version 4.0 (LI-COR Biosciences).

\section{Carboxyfluorescein Succinimidyl Ester Labeling}

$\mathrm{CD}^{+} 4^{+}$cells were maintained in culture medium (IMDM [Invitrogen], BIT9500 [Stem Cell Technologies], and CC100) at 1- 
Table 2. Yields of various cell types isolated from femoral heads

\begin{tabular}{|c|c|c|c|c|c|c|}
\hline Sample ID & $\begin{array}{l}\text { Age, } \\
\text { years }\end{array}$ & WBC & MNC & $\mathrm{CD} 34^{+}$ & $\mathrm{CD}^{+}$ & $\mathrm{CD} 14^{+}$ \\
\hline 1 & 74 & nd & $5.90 \mathrm{E}+07$ & $3.60 \mathrm{E}+05$ & $2.70 \mathrm{E}+05$ & $6.50 \mathrm{E}+05$ \\
\hline 2 & 46 & $7.50 \mathrm{E}+07$ & $3.20 \mathrm{E}+07$ & $5.20 \mathrm{E}+05$ & $6.80 \mathrm{E}+05$ & $1.20 \mathrm{E}+06$ \\
\hline 3 & 68 & $1.25 \mathrm{E}+08$ & $9.50 \mathrm{E}+07$ & $6.06 \mathrm{E}+05$ & $4.10 \mathrm{E}+05$ & $4.02 \mathrm{E}+05$ \\
\hline 4 & 87 & $1.31 \mathrm{E}+07$ & $2.43 \mathrm{E}+07$ & $6.97 \mathrm{E}+05$ & $1.97 \mathrm{E}+06$ & $5.33 \mathrm{E}+05$ \\
\hline 5 & 67 & $1.63 \mathrm{E}+08$ & $1.44 \mathrm{E}+08$ & $8.62 \mathrm{E}+05$ & $3.55 \mathrm{E}+06$ & $3.15 \mathrm{E}+06$ \\
\hline 6 & 54 & nd & $6.30 \mathrm{E}+07$ & $1.30 \mathrm{E}+06$ & $1.90 \mathrm{E}+06$ & $1.00 \mathrm{E}+06$ \\
\hline 7 & 84 & $9.54 \mathrm{E}+07$ & $9.01 \mathrm{E}+07$ & $1.31 \mathrm{E}+06$ & $1.99 \mathrm{E}+06$ & $1.04 \mathrm{E}+06$ \\
\hline 8 & 40 & $1.00 \mathrm{E}+08$ & $9.30 \mathrm{E}+07$ & $1.40 \mathrm{E}+06$ & $1.70 \mathrm{E}+06$ & $1.30 \mathrm{E}+06$ \\
\hline 9 & 70 & $1.44 \mathrm{E}+08$ & $5.26 \mathrm{E}+07$ & $1.40 \mathrm{E}+06$ & $1.46 \mathrm{E}+05$ & $4.78 \mathrm{E}+05$ \\
\hline 10 & 68 & $1.22 \mathrm{E}+08$ & $1.06 \mathrm{E}+08$ & $1.47 \mathrm{E}+06$ & $1.66 \mathrm{E}+06$ & $1.72 \mathrm{E}+06$ \\
\hline 11 & 43 & $2.75 \mathrm{E}+08$ & $2.52 \mathrm{E}+08$ & $1.78 \mathrm{E}+06$ & $2.28 \mathrm{E}+06$ & $3.19 \mathrm{E}+06$ \\
\hline 12 & 68 & $1.23 \mathrm{E}+08$ & $8.89 \mathrm{E}+07$ & $2.13 \mathrm{E}+06$ & $4.03 \mathrm{E}+06$ & $2.76 \mathrm{E}+06$ \\
\hline 13 & 62 & $1.40 \mathrm{E}+08$ & $1.30 \mathrm{E}+08$ & $2.58 \mathrm{E}+06$ & $2.86 \mathrm{E}+06$ & $3.77 \mathrm{E}+06$ \\
\hline 14 & 41 & $2.59 \mathrm{E}+08$ & $2.49 \mathrm{E}+08$ & $3.60 \mathrm{E}+06$ & $3.07 \mathrm{E}+06$ & $4.61 \mathrm{E}+06$ \\
\hline 15 & 63 & nd & $1.30 \mathrm{E}+08$ & $4.80 \mathrm{E}+06$ & $5.60 \mathrm{E}+06$ & nd \\
\hline 16 & 64 & nd & $2.04 \mathrm{E}+08$ & $9.90 \mathrm{E}+06$ & nd & nd \\
\hline 17 & 41 & $9.48 \mathrm{E}+06$ & $7.24 \mathrm{E}+06$ & nd & $1.05 \mathrm{E}+05$ & nd \\
\hline 18 & 66 & $2.11 \mathrm{E}+06$ & $1.62 \mathrm{E}+05$ & na & na & na \\
\hline 19 & 67 & $2.61 \mathrm{E}+07$ & $7.61 \mathrm{E}+06$ & na & na & na \\
\hline 20 & 56 & nd & $4.93 \mathrm{E}+06$ & na & na & na \\
\hline 21 & 61 & $3.60 \mathrm{E}+06$ & na & na & na & na \\
\hline Mean & 61.43 & $1.05 \mathrm{E}+08$ & $9.16 \mathrm{E}+07$ & $2.17 \mathrm{E}+06$ & $2.01 \mathrm{E}+06$ & $1.84 \mathrm{E}+06$ \\
\hline Median & 64 & $1.11 \mathrm{E}+08$ & $8.95 \mathrm{E}+07$ & $1.40 \mathrm{E}+06$ & $1.94 \mathrm{E}+06$ & $1.25 \mathrm{E}+06$ \\
\hline Minimum & 40 & $2.11 \mathrm{E}+06$ & $1.62 \mathrm{E}+05$ & $3.60 \mathrm{E}+05$ & $1.05 \mathrm{E}+05$ & $4.02 \mathrm{E}+05$ \\
\hline Maximum & 87 & $2.75 \mathrm{E}+08$ & $2.52 \mathrm{E}+08$ & $9.90 \mathrm{E}+06$ & $5.60 \mathrm{E}+06$ & $4.61 \mathrm{E}+06$ \\
\hline Sample count & 21 & - & 20 & 16 & 16 & 14 \\
\hline
\end{tabular}

MNC, mononuclear cell; nd, not determined; na, not available.

$2 \times 10^{6} / \mathrm{mL}$. Carboxyfluorescein succinimidyl ester (CFSE) labeling was performed according to the manufacturer's protocol (Molecular Probes, Thermo Fisher Scientific). In brief, CFSE was diluted to $5 \mathrm{mM}$ in DMSO immediately prior to use, then diluted to $5 \mu \mathrm{M}$ in PBS at $37^{\circ} \mathrm{C}$. Cells were incubated in $5 \mu \mathrm{M} \mathrm{CFSE}$ for $15 \mathrm{~min}$ at $37^{\circ} \mathrm{C}$ in the dark. Cells were centrifuged, resuspended in culture medium, and placed in a $37^{\circ} \mathrm{C}$ incubator for $30 \mathrm{~min}$. Cells were centrifuged, supernatant was removed, and resuspended in $100 \mu \mathrm{L}$ of culture medium and placed at $37^{\circ} \mathrm{C}$ for $72 \mathrm{~h}$. Peaks $1-4$ were sorted (488 nm excitation, 525/50 detection) on an FACS Aria II (BD Biosciences), and images were prepared with FlowJo Software version 10 for Windows.

\section{Quantitative Real-Time PCR}

RNA was extracted (RNeasy Mini Kit; Qiagen, Valencia, CA, USA) and cDNA synthesized (iScript cDNA Synthesis Kit; BioRad) following the manufacturer's protocols. qRT-PCR was performed with SsoAdvanced SYBR Green Supermix (Bio-Rad) in a CFX96 Real-Time System (Bio-Rad) using primers for $\beta$-glucuronidase (GUS):

- GUS-F: 5'-GAAAATATGTGGTTGGAGAGCTCATT-3';

- GUS-R: 5'-CCGAGTGAAGATCCCCTTTTTA-3'.
Reactions were incubated at $95^{\circ} \mathrm{C}$ for $3 \mathrm{~min}$, then subjected to 40 cycles of $95^{\circ} \mathrm{C}$ for $10 \mathrm{~s}$ and $55^{\circ} \mathrm{C}$ for $30 \mathrm{~s}$. Each sample was analyzed in triplicate, and replicates were averaged. Data were analyzed with CFX Manager 3.1 software (Bio-Rad).

\section{Results}

\section{Femoral Heads Provide Abundant Hematopoietic \\ Cells}

Femoral heads from 21 patients were collected and processed. Of these, 16 samples yielded sufficient cells for purification based on surface expression of $\mathrm{CD}_{3} 4^{+}$and $\mathrm{CD}^{+}$cells, and 14 for additional purification of $\mathrm{CD} 14^{+}$ cells (Table 2; Fig. 1a). Similar data for 5 CB samples are shown in Table 3. 


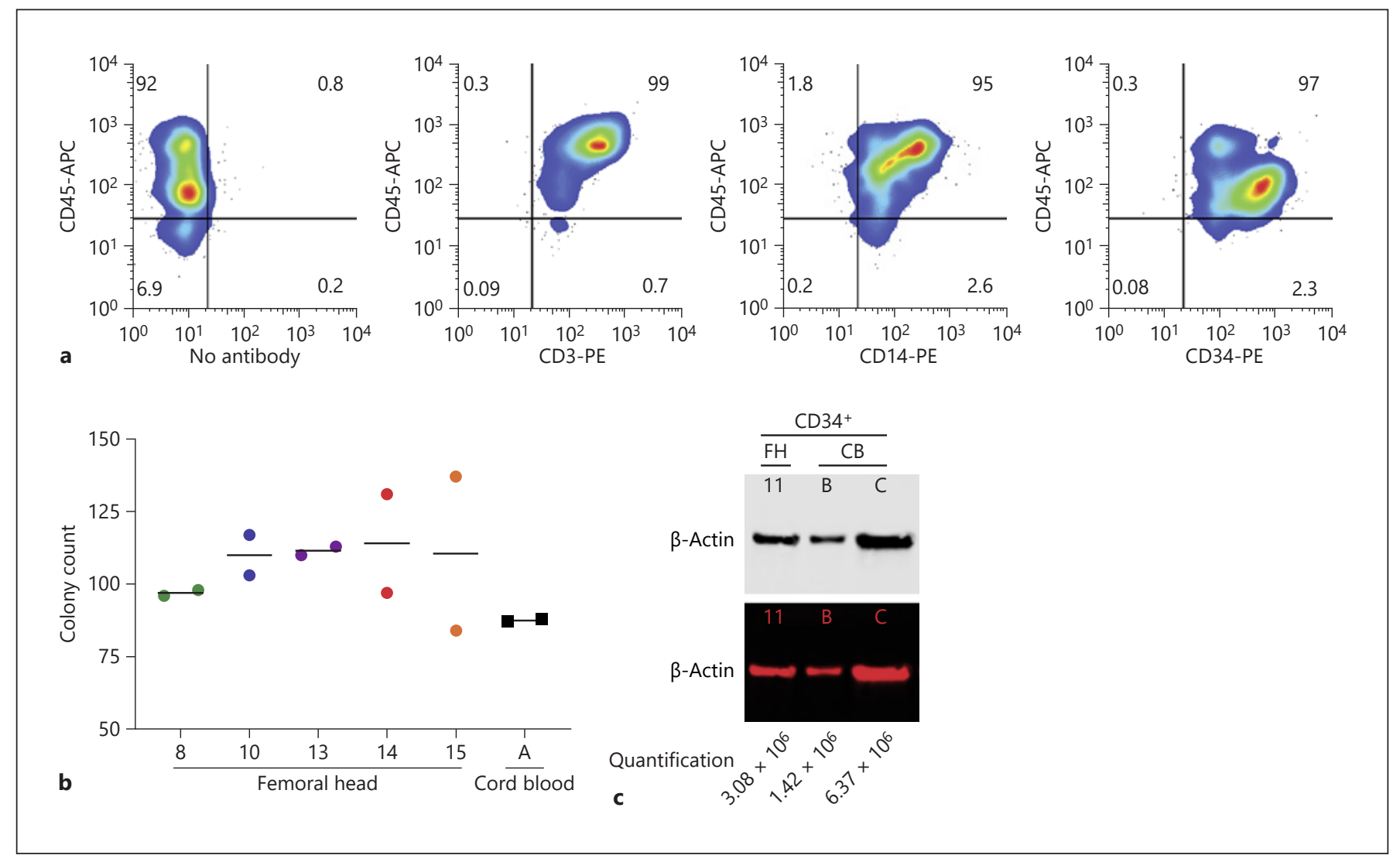

Fig. 1. Femoral heads (FHs) are a source of abundant hematopoietic cells. a Flow cytometry plots of cells from a representative $\mathrm{FH}$ (Sample 7) following cell separation with CD3, CD14, or CD34 microbeads are shown and demonstrate high purity for each cell type. b CD $34^{+}$cells from $5 \mathrm{FH}$ samples (Sample \# indicated along $x$-axis) and 1 cord blood (CB) sample were grown in methylcellulose with cytokines and colonies were counted after 14 days. The

\section{Femoral Head CD34+ Cells Produce Colonies after Storage in Liquid Nitrogen}

Previously frozen $\mathrm{CD} 34^{+}$cells from 5 femoral heads were cultured for $72 \mathrm{~h}$, then evaluated by colony-forming assay (Fig. 1b). The average yield of colonies per sample was 108.6 (per $2 \times 10^{3} \mathrm{CD} 34^{+}$cells), with a median of 106.5 (standard deviation, 16.5; range, 84-137). CD34 ${ }^{+}$cells from 1 fresh CB sample were analyzed with the same approach and grew 87 colonies in dish 1 and 88 colonies in dish 2 .

\section{Femoral Head CD $34^{+}$Cells Yield Sufficient Protein for Analysis by Western Blot}

Protein lysates from CD $34^{+}$cells (equivalent to $1.3 \times$ $10^{5}$ cells/lane) were analyzed by Western blot for $\beta$-actin. Femoral head sample 11 showed a $\beta$-actin band of intensity between the $2 \mathrm{CB}$ samples (Fig. 1c). Quantification mean of 2 plates are shown as short black lines for each sample. Circles and squares of the same color represent the replicates for a given sample. Data from these samples were published in a normalized format in Heaton et al. [10]. c CD34 cells from $1 \mathrm{FH}$ and 2 CB samples were evaluated by Western blot with anti- $\beta$-actin and IRDye 800 . The traditional black and white image and the fluorescent image are shown.

Table 3. Yields of CD $34^{+}$and $\mathrm{CD} 34^{-}$cells isolated from cord blood samples

\begin{tabular}{lll}
\hline Sample ID & $\mathrm{CD}^{+}$ & $\mathrm{CD}^{+}$ \\
\hline $\mathrm{A}$ & $6.16 \mathrm{E}+05$ & $6.00 \mathrm{E}+07$ \\
$\mathrm{~B}$ & $2.80 \mathrm{E}+06$ & nd \\
$\mathrm{C}$ & $1.80 \mathrm{E}+06$ & $5.70 \mathrm{E}+07$ \\
$\mathrm{D}$ & $1.06 \mathrm{E}+06$ & $1.06 \mathrm{E}+08$ \\
$\mathrm{E}$ & $2.77 \mathrm{E}+06$ & $1.05 \mathrm{E}+08$ \\
Mean & $1.81 \mathrm{E}+06$ & $8.20 \mathrm{E}+07$ \\
Median & $1.80 \mathrm{E}+06$ & $8.25 \mathrm{E}+07$ \\
Minimum & $6.16 \mathrm{E}+05$ & $5.70 \mathrm{E}+07$ \\
Maximum & $2.80 \mathrm{E}+06$ & $1.06 \mathrm{E}+08$ \\
Sample count & 5 & 4 \\
\hline
\end{tabular}

nd, not determined. 


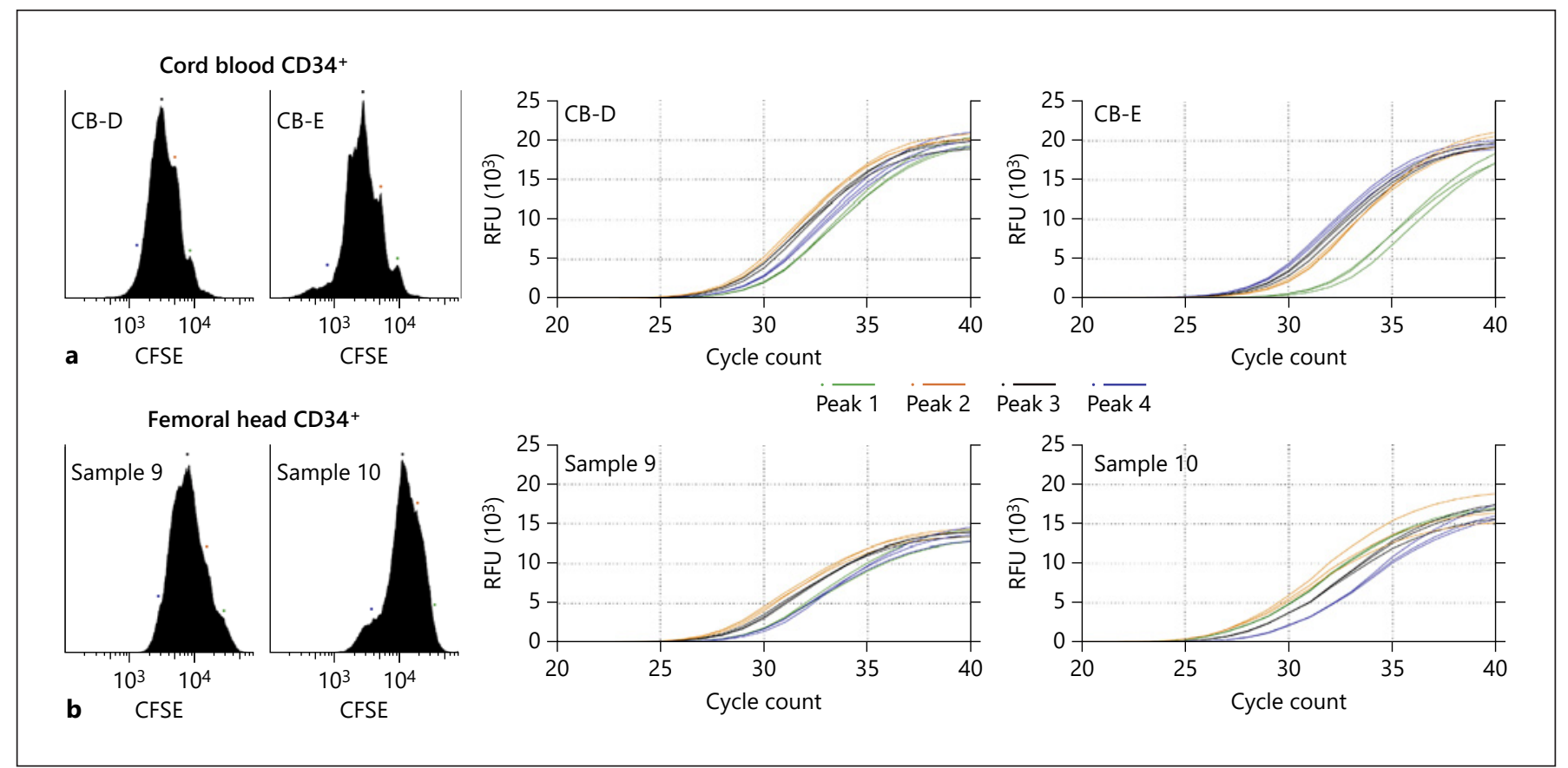

Fig. 2. Femoral head $\mathrm{CD} 34^{+}$cells proliferate ex vivo. Two samples of each, cord blood (a) and femoral head (b) CD $34^{+}$cells, were incubated with CFSE, cultured for $72 \mathrm{~h}$, and then sorted into 4 populations based on CFSE fluorescence (peaks 1-4, noted by colored dots on the histograms). RNA was isolated from each peak, and qRT-PCR was used to quantify $\beta$-glucuronidase (GUS) expression. The relative fluorescent units (RFU) for cycles 20-40 are shown in the panels on the right. showed the femoral head band to be $3.08 \times 10^{6}$ fluorescent units and the $2 \mathrm{CB}$ bands were $1.42 \times 10^{6}$ and $6.37 \times$ $10^{6}$ fluorescent units.

\section{Femoral Head CD34 ${ }^{+}$Cells Divide and Expand in vitro}

To determine whether femoral head $\mathrm{CD} 34^{+}$cells are able to proliferate ex vivo, we performed cell division tracing with CFSE. Figure 2 shows the CFSE distribution for $2 \mathrm{CB}$ and 2 femoral head CD $34^{+}$cultures. The CB samples show well-delineated peaks representing multiple cell divisions and both femoral head samples appear similar, albeit with less peak definition.

\section{Yields of RNA from Expanded Femoral Head CD34+ Cells}

RNA was isolated from the sorted CFSE peaks 1-4, and the yields of cells and RNA are shown in Table 4. RNA was converted to cDNA and analyzed by qRT-PCR for GUS (Fig. 2). $C_{t}$ values for the 2 femoral head samples ranged from 26.44 to 28.90 and from 27.47 to 30.70 for the $2 \mathrm{CB}$ samples. This outcome shows that as few as $2 \times 10^{5}$ femoral head-derived CD $34^{+}$cells (an amount obtained from
16/21 femoral heads and 16/16 with $>3 \times 10^{7} \mathrm{MNC}$ ) will survive and divide in liquid culture, and even after sorting into 4 populations will provide sufficient RNA for gene expression analysis by qRT-PCR. The similarities to $\mathrm{CB}$ make clear that existing protocols in use with $\mathrm{CB}$ cells could be reliably applied to femoral head cells.

\section{Discussion}

As most hematologic malignancies occur in patients over the age of 60 , and the hematopoietic system undergoes profound physiological changes upon aging, it is critical to distinguish aberrancies caused by malignant transformation from age-related physiological alterations. For instance, it is well established that the aging hematopoietic system exhibits inflammatory changes and a myelomonocytic bias $[11,12]$. However, umbilical CB cells are frequently used as controls, although there is convincing data that these cells are functionally different from adult hematopoietic cells, even if matched for the expression of surface markers [6]. Various types of bone marrow cells are available from scientific supply companies, but at costs 
Table 4. Spectrophotometry data from RNA from sorted cultured cells

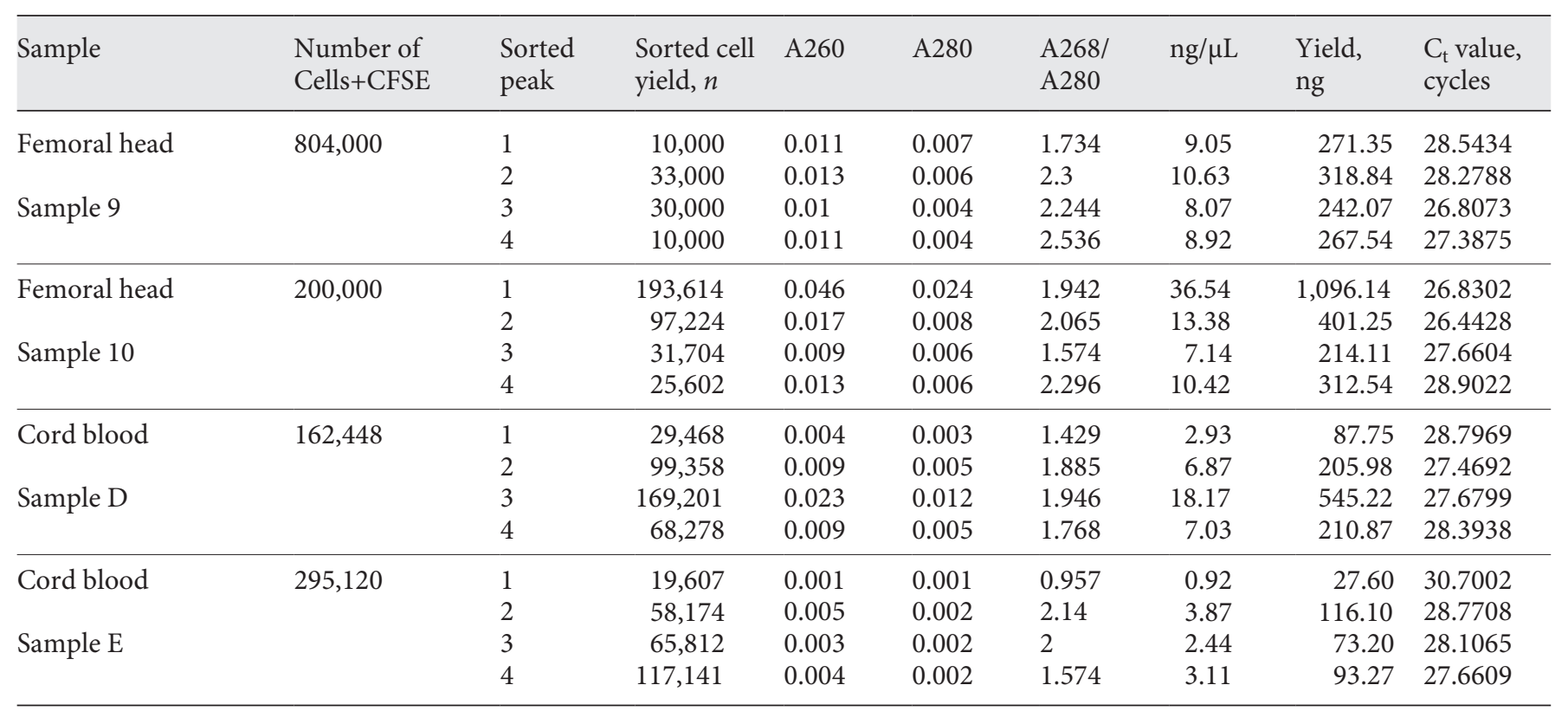

Peak 1 is the highest abundance of CFSE, and Peak 4 is the lowest. CFSE, carboxyfluorescein succinimidyl ester.

that are often prohibitive to academic laboratories. Moreover, proper matching for parameters such as gender, age, and smoking history is difficult, as clinical annotation is limited or absent. We demonstrate the femoral heads removed during THA provide abundant functional mononuclear and $\mathrm{CD} 34^{+}$cells as controls. A previous study reported on the utility of femoral head bone marrow for verification of cutoffs in flow cytometry evaluation of myelodysplastic syndromes [8]. Another study compared iliac crest, vertebral body, and femoral head MNCs as a source of mesenchymal stromal cells [9]. Femoral head MNC yields were comparable to ours, but somewhat lower than those of iliac crest or vertebral body. No significant functional differences were seen in the MNCs, except that femoral head-derived mesenchymal stromal cells were less responsive to chondrogenic induction. However, as the donors of femoral heads were significantly older (median age 81 , range 51-91 years) than the donors of iliac crest and vertebral body cells (median age 46, range 14-88 years), it seems more plausible that these differences are age-related. Data on hematopoietic cells were not provided. A previous study of femoral head-derived hematopoietic cells by Rundberg Nilsson et al. [7] demonstrated that the distributions of various stem and progenitor cell types in marrow from femoral heads are distinct from those in umbilical $\mathrm{CB}$. They also demonstrated that $\mathrm{CB}$ and femoral head lineage ${ }^{-} \mathrm{CD} 34^{+} \mathrm{CD} 123^{\text {low/- }} \mathrm{CD} 4 \mathrm{RA}^{-} \mathrm{CD} 90^{+}$ cells exhibit distinct proliferative capacity. Femoral headderived cells were phenotypically and functionally more similar to cells derived from iliac crest aspiration than to $\mathrm{CB}$ cells. These data support our conclusions that femoral head-derived cells are suitable as controls. Our data demonstrate that femoral head-derived hematopoietic cells proliferate ex vivo, form abundant colonies, and provide sufficient material for protein and mRNA-based analysis. The collection and processing of femoral heads can fit easily into the workflow of biobanks and individual laboratories. In summary, femoral heads provide a source of healthy, older adult hematopoietic cells for use in a variety of laboratory experiments.

\section{Acknowledgements}

We are grateful to the patients who donated their femoral heads for use in this study. We thank them and hope they are recovering well. We thank Marissa L. Stagg and Nadia Hamad at the Department of Orthopaedic Surgery, University of Utah, for assistance in acquiring the femoral heads. 


\section{Statement of Ethics}

Written informed consent was obtained from each total hip arthroplasty patient under the IRB study protocol 77125 (University of Utah, M.W.D.).

\section{Conflict of Interest Statement}

M.W.D. declares the following - consulting: Blueprint, Fusion Pharma, Novartis, Sangamo, Ascentage Pharma, Adelphi, CTI, BMS, Pfizer, and Takeda; honoraria: Blueprint, Fusion Pharma, Takeda, Medscape, Novartis, Incyte, Sangamo, Pfizer, Dispersol, Adelphi, Humana, Ascentage Pharma, TRM, Ariad, Galena BioPharma, BMS, CTI BioPharma, Celgene, and Gilead; research support: Takeda, Novartis, Pfizer, Incyte, SPARC, TetraLogic Pharmaceuticals, and Blueprint; advisory board: Blueprint, Takeda, Medscape, Incyte, Sangamo, Ascentage Pharma, Humana, TRM, Ariad, Galena Biopharma, and Pfizer. Other authors have no conflicts of interest to declare.

\section{Funding Sources}

This work was supported by the National Institutes of Health National Cancer Institute grant R01CA178397 (M.W.D. and T.O.). The University of Utah Flow Cytometry Facility is supported by the National Cancer Institute through award 5P30CA042014-24 and the National Center for Research Resources of the National Institutes of Health under award 1S10RR026802-01. D.Y. is supported by the International Award from the Lady Tata Memorial Trust and was previously supported by the Special Fellow Award from the Leukemia \& Lymphoma Society. A.M.E. was supported by a Research Training Award for Fellows from the American Society of Hematology.

\section{Author Contributions}

M.B.A. and S.M.R.: coordinated patients, schedules, screening, and consents. J.G.: performed surgery and directed clinical team. P.M.C., A.D.P., D.Y., W.L.H., and A.M.E.: extracted cells and performed experiments. T.O. and M.W.D.: directed laboratory studies. A.D.P., P.M.C., T.O., and M.W.D.: analyzed data and wrote manuscript.

\section{References}

1 Patel AB, Vellore NA, Deininger MW. New strategies in myeloproliferative neoplasms: the evolving genetic and therapeutic landscape. Clin Cancer Res. 2016;22(5):1037-47.

2 Rollison DE, Howlader N, Smith MT, Strom SS, Merritt WD, Ries LA, et al. Epidemiology of myelodysplastic syndromes and chronic myeloproliferative disorders in the United States, 2001-2004, using data from the NAACCR and SEER programs. Blood. 2008; 112(1):45-52.

3 Khorashad JS, Eiring AM, Mason CC, Gantz $\mathrm{KC}$, Bowler AD, Redwine HM, et al. shRNA library screening identifies nucleocytoplasmic transport as a mediator of BCR-ABL1 kinase-independent resistance. Blood. 2015; 125(11):1772-81.

4 Eiring AM, Page BDG, Kraft IL, Mason CC, Vellore NA, Resetca D, et al. Combined STAT3 and BCR-ABL1 inhibition induces synthetic lethality in therapy-resistant chronic myeloid leukemia. Leukemia. 2015;29(3): 586-97.
5 Vadillo E, Dorantes-Acosta E, Arriaga-Pizano L, Chavez-Gonzalez A, Reyes-Maldonado E, Garrett KP, et al. Adult, but not neonatal, human lymphoid progenitors respond to TLR9 ligation by producing functional NK-like cells. Exp Hematol. 2014;42(7):562-73.e3.

6 Nicolini FE, Holyoake TL, Cashman JD, Chu PP, Lambie K, Eaves CJ. Unique differentiation programs of human fetal liver stem cells shown both in vitro and in vivo in NOD/SCID mice. Blood. 1999;94(8):2686-95.

7 Rundberg Nilsson A, Soneji S, Adolfsson S, Bryder D, Pronk CJ. Human and murine hematopoietic stem cell aging is associated with functional impairments and intrinsic megakaryocytic/erythroid bias. PLoS One. 2016; 11(7):e0158369.

8 van Gammeren AJ, van Rijckevorsel M, Bras AE, Brandt-Hagens C, Te Marvelde JG, de Visser C, et al. Usability of femoral head bone marrow to verify reference ranges for the assessment of myelodysplasia by flow cytometry. Int J Lab Hematol. 2018;40(6):726-33.
9 Herrmann M, Hildebrand M, Menzel U, Fahy $\mathrm{N}$, Alini M, Lang S, et al. Phenotypic characterization of bone marrow mononuclear cells and derived stromal cell populations from human iliac crest, vertebral body and femoral head. Int J Mol Sci. 2019;20(14):3454.

10 Heaton WL, Senina AV, Pomicter AD, Salama ME, Clair PM, Yan D, et al. Autocrine Tnf signaling favors malignant cells in myelofibrosis in a Tnfr2-dependent fashion. Leukemia. 2018;32(11):2399-411.

11 Pang WW, Price EA, Sahoo D, Beerman I, Maloney WJ, Rossi DJ, et al. Human bone marrow hematopoietic stem cells are increased in frequency and myeloid-biased with age. Proc Natl Acad Sci U S A. 2011;108(50): 20012-7.

12 Kovtonyuk LV, Fritsch K, Feng X, Manz MG, Takizawa H. Inflamm-aging of hematopoiesis, hematopoietic stem cells, and the bone marrow microenvironment. Front Immunol. 2016;7:502 